\title{
FEDERACJA ROSYJSKA
}

\section{USTAWA FEDERALNA \\ O JURYSDYKCYJNYCH IMMUNITETACH OBCYCH PAŃSTW I MAJĄTKU OBCEGO PAŃSTWA W FEDERACJI ROSYJSKIEJ ${ }^{1}$}

Przyjęta przez Dumę Państwową 23 października 2015 r.

Zatwierdzona przez Radę Federacji 28 października 2015 r.

\section{Artykuł 1. Przedmiot regulacji niniejszej Ustawy Federalnej}

1. Niniejsza Ustawa Federalna reguluje stosunki związane z zastosowaniem przez Federację Rosyjską jurysdykcyjnych immunitetów obcego państwa i jego majątku.

2. Obce państwo w stosunku do siebie i swojego majątku korzysta z jurysdykcyjnych immunitetów z uwzględnieniem założeń niniejszej Ustawy Federalnej.

3. Postanowienia niniejszej Ustawy Federalnej stosuje się, jeżeli Federacja Rosyjska i obce państwo nie postanowią inaczej.

\section{Artykuł 2. Podstawowe pojęcia zastosowane w niniejszej Ustawie Federalnej}

Do celów niniejszej Ustawy Federalnej stosuje się następujące podstawowe pojęcia:

1. obce państwo

a) inne państwo niż Federacja Rosyjska i jego organy władzy państwowej,

b) części składowe danego państwa obcego (podmioty obcego państwa federalnego lub administracyjno-terytorialne formacje obcego państwa) i ich organy w stopniu, w jakim są one uprawnione 
wypełniać działania w celach sprawowania suwerennej władzy danego obcego państwa i funkcjonują w tym charakterze,

c) instytucje lub inne formacje niezależnie od tego, czy są one osobami prawnymi $\mathrm{w}$ takim stopniu, $\mathrm{w}$ jakim są one uprawnione wykonywać i faktycznie wykonują działania w celach realizacji suwerennej władzy danego obcego państwa,

d) przedstawiciele danego obcego państwa, funkcjonujący w tym charakterze,

2. mienie obcego państwa - majątek należący do obcego państwa i znajdujący się na terytorium Federacji Rosyjskiej,

3. jurysdykcyjne immunitety obcego państwa i jego mienia - immunitet sądowy, immunitet dotyczący środków zabezpieczenia powództwa i immunitet dotyczący wykonania wyroku sądu,

4. immunitet sądowy - obowiązek sądu Federacji Rosyjskiej wstrzymania się od włączenia obcego państwa do udziału w procesie sądowym,

5. immunitet dotyczący środków zabezpieczenia powództwa - obowiązek sądu Federacji Rosyjskiej wstrzymania się od zastosowania w stosunku do obcego państwa i mienia obcego państwa zajęcia i innych środków, zapewniających w następstwie rozpatrzenie sporu i (lub) wykonanie wyroku sądu,

6. immunitet dotyczący wykonania wyroku sądu - obowiązek sądu Federacji Rosyjskiej lub federalnego organu władzy wykonawczej realizującego funkcje dotyczące wykonywania aktów sądowych, aktów innych organów i osób urzędowych wstrzymania się od egzekucji kary z mienia obcego państwa, przyjęcia w stosunku do obcego państwa i jego mienia innych środków egzekucji wyroku sądu,

7. sąd Federacji Rosyjskiej - Sąd Najwyższy Federacji Rosyjskiej, federalny sąd powszechny, sąd arbitrażowy, utworzone zgodnie z Konstytucją Federacji Rosyjskiej, federalnymi ustawami konstytucyjnymi i ustawami federalnymi,

8. suwerenne uprawnienia władcze - uprawnienia, które obce państwo posiada z mocy suwerenności, sprawowane $\mathrm{w}$ celach realizacji suwerennej władzy. 


\section{Artykuł 3. Przywileje i immunitety, na które niniejsza Ustawa Federalna nie ma wpływu}

1. Niniejsza Ustawa Federalna nie narusza przywilejów i immunitetów, z których zgodnie z normami prawa międzynarodowego korzysta obce państwo w kwestii sprawowania funkcji przez przedstawicielstwa dyplomatyczne, instytucje konsularne, misje specjalne, przedstawicielstwa przy organizacjach międzynarodowych lub delegacje w organach organizacji międzynarodowych bądź na konferencjach międzynarodowych i odnoszące się do nich osoby.

2. Niniejsza Ustawa Federalna nie narusza przywilejów i immunitetów, udzielonych zgodnie $\mathrm{z}$ normami prawa międzynarodowego głowom państw, rządom lub ministrom spraw zagranicznych.

3. Niniejsza Ustawa Federalna nie narusza immunitetów, z których zgodnie z normami prawa międzynarodowego korzysta obce państwo w kwestii statków powietrznych lub obiektów kosmicznych należących do obcego państwa lub eksploatowanych przez nie, a także okrętów wojennych i innych eksploatowanych w celach niekomercyjnych statków państwowych.

\section{Artykuł 4. Zasada wzajemności w kwestiach stosowania immunitetów jurysdykcyjnych}

1. Jurysdykcyjne immunitety obcego państwa i jego mienia w zakresie udzielonym zgodnie z niniejszą Ustawą Federalną mogą zostać ograniczone na podstawie zasady wzajemności, jeżeli zostanie stwierdzona obecność ograniczeń dotyczących udzielenia Federacji Rosyjskiej i jej mieniu jurysdykcyjnych immunitetów w obcym państwie, w stosunku do którego i jego majątku powstała wątpliwość co do kwestii immunitetów jurysdykcyjnych.

2. Federalny organ władzy wykonawczej, sprawujący funkcje opracowania i realizacji polityki państwowej i normatywnego regulowania w sferze stosunków międzynarodowych Federacji Rosyjskiej, w trybie ustanowionym ustawodawstwem procesowym Federacji Rosyjskiej, opiniuje wnioski w kwestiach udzielenia Federacji Rosyjskiej i jej mieniu immunitetów jurysdykcyjnych w obcym państwie.

\section{Artykuł 5. Zgoda obcego państwa na sprawowanie jurysdykcji przez sąd Federacji Rosyjskiej}

1. Obce państwo nie korzysta w Federacji Rosyjskiej z immunitetu sądowego, jeżeli wyraźnie wyraziło zgodę na sprawowanie przez sąd Federacji Rosyjskiej jurysdykcji dotyczącej konkretnego sporu z mocy: 
1) umowy międzynarodowej,

2) pisemnej zgody niebędącej umową międzynarodową,

3) oświadczenia w sądzie Federacji Rosyjskiej, pisemnego zawiadomienia sądu Federacji Rosyjskiej lub pisemnego zawiadomienia przekazanego Federacji Rosyjskiej kanałami dyplomatycznymi w zakresie procesu sądowego dotyczącego konkretnego sporu.

2. Zgoda obcego państwa na sprawowanie przez sąd Federacji Rosyjskiej jurysdykcji dotyczącej konkretnego sporu, przewidziana w punkcie 1 niniejszego artykułu, nie może zostać odwołana i rozszerza się na wszystkie etapy rozprawy sądowej.

3. W charakterze zgody obcego państwa na sprawowanie przez sąd Federacji Rosyjskiej jurysdykcji dotyczącej konkretnego sporu nie są rozpatrywane:

1) przystąpienie obcego państwa do procesu sądowego lub realizowanie dowolnego innego działania procesowego wyłącznie w celu oświadczenia o jurysdykcyjnych immunitetach lub przedstawienia dowodów istnienia prawa w stosunkach majątkowych, które są przedmiotem sporu,

2) zgoda obcego państwa na zastosowanie ustawodawstwa Federacji Rosyjskiej w stosunku do konkretnego sporu,

3) brak uczestnictwa obcego państwa w procesie sądowym w sądzie Federacji Rosyjskiej,

4) stawiennictwo przedstawiciela obcego państwa w sądzie Federacji

Rosyjskiej w celu złożenia zeznań jako świadek lub w charakterze eksperta.

4. Zgoda obcego państwa na sprawowanie przez sąd Federacji Rosyjskiej jurysdykcji dotyczącej konkretnego sporu nie godzi w immunitet obcego państwa dotyczący środków zabezpieczenia powództwa i (lub) immunitet obcego państwa dotyczący wykonania wyroku sądu.

\section{Artykuł 6. Zrzeczenie się immunitetu sądowego}

1. Za obce państwo zrzekające się immunitetu sądowego uznaje się takie obce państwo, które wniosło powództwo do sądu Federacji Rosyjskiej, merytorycznie uczestniczyło $\mathrm{w}$ procesie sądowym w sądzie Federacji Rosyjskiej w charakterze podmiotu uczestniczącego w sprawie lub podjęło inne istotne merytoryczne czynności.

2. Za obce państwo zrzekające się immunitetu sądowego w kwestii sporów dotyczących arbitrażowego lub rozjemczego porozumienia 
uznaje się obce państwo, które zawarło arbitrażowe lub rozjemcze porozumienie o rozstrzyganiu z jego udziałem sporów, które powstały lub mogą powstać w przyszłości w związku z wykonywaniem obowiązków.

3. Za obce państwo zrzekające się immunitetu sądowego dotyczącego dowolnego wzajemnego powództwa uznaje się państwo, które to obce państwo wniosło powództwo do sądu Federacji Rosyjskiej.

4. Za obce państwo zrzekające się immunitetu sądowego dotyczącego powództwa pierwotnego uznaje się obce państwo, które wniosło do sądu Federacji Rosyjskiej powództwo wzajemne.

5. Zrzeczenie się immunitetu sądowego dotyczącego konkretnego sporu przez obce państwo nie może zostać odwołane i obejmuje wszystkie fazy postępowania sądowego.

6. Zrzeczenie się immunitetu sądowego dotyczącego konkretnego sporu przez obce państwo nie jest rozpatrywane jako zrzeczenie się danego obcego państwa immunitetu dotyczącego środków zabezpieczenia powództwa i immunitetu dotyczącego wykonania wyroku sądu.

Artykuł 7. Niestosowanie immunitetu sądowego w zakresie sporów związanych z udziałem obcego państwa w czynnościach cywilnoprawnych i (lub) wykonywaniem przedsiębiorczej i innej działalności gospodarczej

1. Obce państwo nie korzysta w Federacji Rosyjskiej z immunitetu sądowego dotyczącego sporów związanych z udziałem obcego państwa w czynnościach cywilnoprawnych z osobami fizycznymi albo osobami prawnymi lub innymi podmiotami innego państwa niemającymi statusu osoby prawnej, jeżeli takie spory, zgodnie z zastosowanymi normami prawa, podlegają jurysdykcji sądu Federacji Rosyjskiej i wskazane czynności nie są związane z realizacją przez obce państwo suwerennych uprawnień władczych.

2. Postanowienia punktu 1 niniejszego artykułu nie mają zastosowania, jeżeli wszystkie strony czynności cywilnoprawnych są państwami lub strony tej czynności postanowiły inaczej.

3. Obce państwo nie korzysta w Federacji Rosyjskiej z immunitetu sądowego dotyczącego sporów związanych z wykonywaniem na terytorium Federacji Rosyjskiej przez obce państwo przedsiębiorczej i innej działalności gospodarczej, jak również na terytorium innego państwa, 
jeżeli skutki takiej działalności mają związek z terytorium Federacji Rosyjskiej.

4. Przy rozstrzyganiu kwestii, czy czynność dokonywana przez obce państwo jest związana z wykonywaniem jego suwerennych uprawnień władczych, sąd Federacji Rosyjskiej bierze pod uwagę charakter i cel takiej czynności.

\section{Artykuł 8. Niestosowanie immunitetu sądowego w stosunku do sporów pracowniczych}

1. Obce państwo nie korzysta w Federacji Rosyjskiej z immunitetu sądowego w stosunku do sporów powstałych w oparciu o umowę o pracę między tym obcym państwem i pracownikiem odnośnie pracy, która była lub powinna zostać w pełni lub częściowo wykonana na terytorium Federacji Rosyjskiej.

2. Postanowienia punktu 1 niniejszego artykułu nie mają zastosowania w przypadku, jeżeli:

1) pracownik został przyjęty do pracy w celu wypełniania konkretnych obowiązków po spełnieniu suwerennych uprawnień władczych obcego państwa,

2) pracownik jest:

a) przedstawicielem dyplomatycznym, jak jest to określone w umowach międzynarodowych,

b) konsularną osobą urzędową, jak to jest określone w umowach międzynarodowych,

c) dyplomatycznym współpracownikiem stałych przedstawicielstw przy organizacjach międzynarodowych, misjach specjalnych lub włączonym w tym charakterze w skład delegacji obcego państwa do organu międzynarodowych organizacji lub na konferencję międzynarodową,

d) dowolną inną osobą korzystającą z immunitetu dyplomatycznego,

3) przedmiotem rozprawy sądowej jest przyjęcie do pracy, kontynuacja wypełniania obowiązków lub przywrócenie do pracy,

4) przedmiotem rozprawy sądowej jest ustanie stosunków pracy z pracownikiem i głowa obcego państwa, szef rządu obcego państwa lub minister spraw zagranicznych obcego państwa potwierdzi w formie pisemnej, że rozprawa wpłynie na interesy bezpieczeństwa tego obcego państwa, 
5) pracownik $\mathrm{w}$ chwili wszczęcia postępowania w sprawie $\mathrm{w}$ sądzie Federacji Rosyjskiej jest obywatelem obcego państwa, z którym zawarł umowę o pracę, z wyjątkiem przypadku gdy pracownik ten zamieszkuje na terytorium Federacji Rosyjskiej.

\section{Artykuł 9. Niestosowanie immunitetu sądowego} w sporach związanych z udziałem osób prawnych lub innych podmiotów, które nie posiadają statusu osoby prawnej

1. Obce państwo nie korzysta w Federacji Rosyjskiej z immunitetu sądowego w stosunku do sporów związanych z udziałem obcego państwa w podmiotach osób prawnych lub innych podmiotach, które nie posiadają statusu osoby prawnej, i powstałym między obcym państwem i osobą prawną zarejestrowaną zgodnie z procedurą ustanowioną ustawodawstwem Federacji Rosyjskiej i (lub) realizując swoją działalność na terytorium Federacji Rosyjskiej, lub innym podmiotem, który nie posiada statusu osoby prawnej, realizującym swoją działalność na terytorium Federacji Rosyjskiej, bądź między obcym państwem i innymi uczestnikami takiej osoby prawnej lub takiego podmiotu, jeżeli taka osoba prawna lub taki podmiot posiada innych uczestników na równi z państwami i (lub) międzypaństwowymi i (lub) międzyrządowymi organizacjami.

2. Postanowienia punktu 1 niniejszego artykułu nie mają zastosowania w przypadkach, jeżeli inaczej:

1) przewidziano $\mathrm{w}$ porozumieniu między odpowiednimi państwami,

2) stanowi dokument powołujący taką osobę prawną lub taki podmiot,

3) przewiduje pisemne uzgodnienie stron sporu.

\section{Artykuł 10. Niestosowanie immunitetu sądowego w sporach dotyczących praw majątkowych}

Obce państwo nie korzysta w Federacji Rosyjskiej z immunitetu sądowego w sporach dotyczących:

1. praw i obowiązków danego państwa obcego w odniesieniu do majątku nieruchomego znajdującego się na terytorium Federacji Rosyjskiej,

2. praw i obowiązków danego państwa obcego w odniesieniu do mienia ruchomego i nieruchomości, które powstają na mocy dziedziczenia, darowizny lub zasiedzenia,

3. praw i obowiązków danego państwa obcego w odniesieniu do zarządzania mieniem. 


\section{Artykuł 11. Niestosowanie immunitetu sądowego w sporach o naprawienie szkód}

Obce państwo nie korzysta w Federacji Rosyjskiej z immunitetu sądowego dotyczącego sporów o naprawienie obcym państwom szkód wyrządzonych przeciwko życiu, zdrowiu, mieniu, czci i godności, zawodowej reputacji osoby fizycznej lub mieniu, zawodowej reputacji osoby prawnej, jeżeli roszczenie powstało $\mathrm{w}$ wyniku wyrządzenia szkód przeciwko życiu, zdrowiu, mieniu, czci i godności, zawodowej reputacji poprzez działanie (zaniechanie) lub w związku z innymi okolicznościami, mającymi całkowicie lub częściowo miejsce na terytorium Federacji Rosyjskiej w chwili takiego działania (zaniechania).

\section{Artykuł 12. Niestosowanie immunitetu sądowego w sporach dotyczących własności intelektualnej}

Obce państwo nie korzysta w Federacji Rosyjskiej z immunitetu sądowego w zakresie sporów związanych z:

1) ustanowieniem i realizacją praw obcego państwa do rezultatów działalności intelektualnej i utożsamianymi z nimi środkami indywidualizacji osób prawnych, towarów, prac, usług i przedsiębiorstw,

2) domniemanym naruszeniem przez obce państwo praw innych osób co do rezultatów działalności intelektualnej i utożsamianymi z nimi środkami indywidualizacji osób prawnych, towarów, prac, usług i przedsiębiorstw.

\section{Artykuł 13. Niestosowanie immunitetu sądowego w sprawach sporów związanych z eksploatacją statku}

1. Obce państwo nie korzysta w Federacji Rosyjskiej z immunitetu sądowego w sprawach sporów związanych z eksploatacją przez obce państwo statku będącego jego własnością albo przez niego eksploatowanego lub służącego do przewozu ładunku, jeżeli w chwili powstania faktu powodującego pojawienie się powództwa statek był przez obce państwo wykorzystywany w innych celach niż niekomercyjne i (lub) ładunek nie okazał się ładunkiem należącym do obcego państwa i wykorzystywanym lub przeznaczonym do realizacji przez niego wyłącznie suwerennych uprawnień władczych.

2. W celu zastosowania niniejszego artykułu stosowane pojęcia rozumie się następująco: 
1) statek - wszystkie rodzaje pływających środków, które wykorzystywane są lub mogą zostać wykorzystane jako środki komunikacji wodnej,

2) statek wykorzystywany w celach niekomercyjnych - statki wykorzystywane do realizacji przez obce państwo suwerennych uprawnień władczych, włączając okręty wojenne i eksploatowane w celach niekomercyjnych statki państwowe,

3) spory dotyczące eksploatacji statku - spory dotyczące:

a) zderzenia statków, uszkodzenia portowych i hydrotechnicznych budowli lub innej awarii żeglugowej,

b) udzielenia pomocy, prac ratowniczych i awarii ogólnej,

c) świadczeń, prac remontowych i innych, świadczenia usług dotyczących statku,

d) następstw zanieczyszczenia środowiska morskiego,

e) wydobycia zatopionego mienia.

\section{Artykuł 14. Immunitet obcego państwa dotyczący środków zabezpieczenia powództwa}

Obce państwo korzysta z immunitetu dotyczącego środków zabezpieczenia powództwa z wyjątkiem przypadków, jeżeli obce państwo:

1) wyraźnie wyraziło zgodę na przyjęcie odpowiednich środków jednego ze sposobów przewidzianych w punkcie 1 artykułu 5 niniejszej Ustawy Federalnej,

2) zarezerwowało lub w inny sposób oznaczyło mienie na wypadek zadośćuczynienia żądaniu będącego przedmiotem sporu.

\section{Artykuł 15. Immunitet obcego państwa dotyczący wykonania wyroku sądu}

Obce państwo korzysta z immunitetu dotyczącego wykonania wyroku sądu z wyjątkiem przypadków, jeżeli:

1) obce państwo wyraźnie wyraziło zgodę na przyjęcie odpowiednich środków jednego ze sposobów przewidzianych w punkcie 1 artykułu 5 niniejszej Ustawy Federalnej,

2) obce państwo zarezerwowało lub w inny sposób oznaczyło mienie na wypadek zadośćuczynienia żądaniu będącego przedmiotem sporu,

3) ustanowiono, że mienie obcego państwa jest wykorzystywane i (lub) przeznaczone do wykorzystania przez dane obce państwo w celach 
niezwiązanych ze sprawowaniem suwerennych uprawnień władczych.

\section{Artykuł 16. Mienie obcego państwa korzystającego z immunitetu dotyczącego środków zabezpieczających powództwo i immunitetu dotyczącego wykonania wyroku sądu}

1. Z immunitetu dotyczącego środków zabezpieczenia powództwa i z immunitetu dotyczącego wykonania wyroku sądu korzysta następujące mienie obcego państwa, będące jego własnością, przeznaczone do wykorzystania lub z którego obce państwo korzysta w swoim imieniu w działalności związanej ze sprawowaniem suwerennych uprawnień władczych:

1) majątek (w tym środki pieniężne, znajdujące się na rachunku bankowym) wykorzystywany lub przeznaczony do sprawowania funkcji przedstawicielstw dyplomatycznych obcego państwa lub jego instytucji konsularnych, misji specjalnych, przedstawicielstw przy organizacjach międzynarodowych, delegacji obcego państwa do organizacji międzynarodowych lub na międzynarodowych konferencjach,

2) majątek wojskowy lub majątek wykorzystywany albo przeznaczony do wykorzystywania w celach wojskowych lub operacjach pokojowych, uznawanych przez Federację Rosyjską,

3) dobra kulturalne lub archiwa, które nie są wystawione na sprzedaż albo te, które nie są przeznaczone do sprzedaży,

4) majątek będący częścią ekspozycji na wystawach, przestawiający naukowe, kulturalne lub historyczne dobro, który nie jest wystawiony na sprzedaż albo ten, który nie jest przeznaczony do sprzedaży,

5) majątek banku centralnego lub innego organu nadzoru obcego państwa, do funkcji którego wchodzi nadzór bankowy.

2. Postanowienia punktu 1 niniejszego artykułu mają zastosowanie z uwzględnieniem postanowień artykułu 14 i punktów 1 i 2 artykułu 15 niniejszej Ustawy Federalnej.

\section{Artykuł 17. Postępowanie w sprawach $\mathrm{z}$ udziałem obcego państwa}

Sprawy z udziałem obcego państwa rozpatruje sąd Federacji Rosyjskiej w trybie ustanowionym ustawodawstwem procesowym Federacji Rosyjskiej. 
Artykuł 18. Wejście w życie niniejszej Ustawy Federalnej

Niniejsza Ustawa Federalna wchodzi w życie z dniem 1 stycznia 2016 r.

Prezydent

Federacji Rosyjskiej

W. Putin

Moskwa, Kreml

3 listopada $2015 \mathrm{r}$.

Nr 297 - UF

tłum. z j. ros. Krystian Nowak*

* Dr, Uniwersytet Rzeszowski; e-mail: nowak@ur.edu.pl, https://orcid.org/00000003-4853-1591. 
